\title{
Moed of methode
}

Citation for published version (APA):

Struijker Boudier, H. A. J. (1999). Moed of methode: vooruitgang in het hart- en vaatziektenonderzoek. Datawyse / Universitaire Pers Maastricht. https://doi.org/10.26481/spe.19990910hsb

\section{Document status and date:}

Published: 10/09/1999

DOI:

10.26481/spe.19990910hsb

Document Version:

Publisher's PDF, also known as Version of record

\section{Please check the document version of this publication:}

- A submitted manuscript is the version of the article upon submission and before peer-review. There can be important differences between the submitted version and the official published version of record.

People interested in the research are advised to contact the author for the final version of the publication, or visit the DOI to the publisher's website.

- The final author version and the galley proof are versions of the publication after peer review.

- The final published version features the final layout of the paper including the volume, issue and page numbers.

Link to publication

\footnotetext{
General rights rights.

- You may freely distribute the URL identifying the publication in the public portal. please follow below link for the End User Agreement:

www.umlib.nl/taverne-license

Take down policy

If you believe that this document breaches copyright please contact us at:

repository@maastrichtuniversity.nl

providing details and we will investigate your claim.
}

Copyright and moral rights for the publications made accessible in the public portal are retained by the authors and/or other copyright owners and it is a condition of accessing publications that users recognise and abide by the legal requirements associated with these

- Users may download and print one copy of any publication from the public portal for the purpose of private study or research.

- You may not further distribute the material or use it for any profit-making activity or commercial gain

If the publication is distributed under the terms of Article $25 \mathrm{fa}$ of the Dutch Copyright Act, indicated by the "Taverne" license above, 


\section{1}

Universiteitsbibliotheek

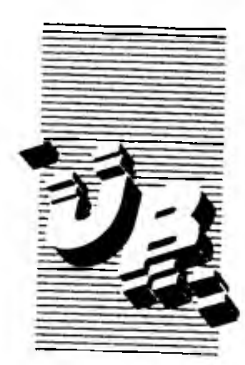

De uitleentermijn verstrijkt op:

\section{JULI 2000 \\ 19 OKT 2000}

\section{DEC. 2002}

Universiteit Maastricht

Postbus 616

6200 MD Maastricht

Gelieve deze publicatie tijdig te retourneren of (telefonisch) verlenging van de uitleentermijn aan te vragen. 


\section{MOED OF METHODE \\ VOORUITGANG IN HET HART- EN \\ VAATZIEKTENONDERZOEK}


(C) H.A.J. Struijker Boudier, Maastricht 1999

\section{ISBN 9052782563}

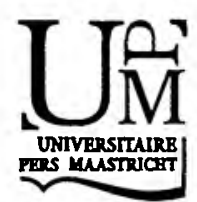




\section{HG

\section{REDE}

\section{UITGESPROKEN}

OP VRIJDAG 10 SEPTEMBER 1999 BIJ ZIJN BENOEMING TOT HOOGLERAAR IN HET ONDERZOEK VAN DE HART- EN VAATZIEKTEN EN WETENSCHAPPELIJK DIRECTEUR VAN HET CARDIOVASCULAIR RESEARCH INSTITUUT MAASTRICHT

\section{DOOR}

PROF.DR. H.A.J.STRUIJKER BOUDIER 
Yves Klein, "Un homme dans l'espace!

Le peintre de l'espace se jette dans le vide"

1960.

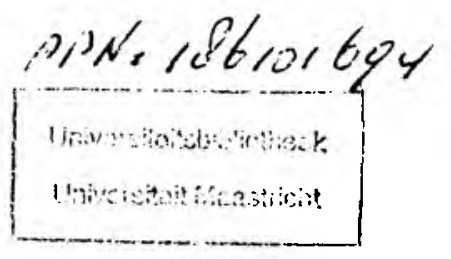




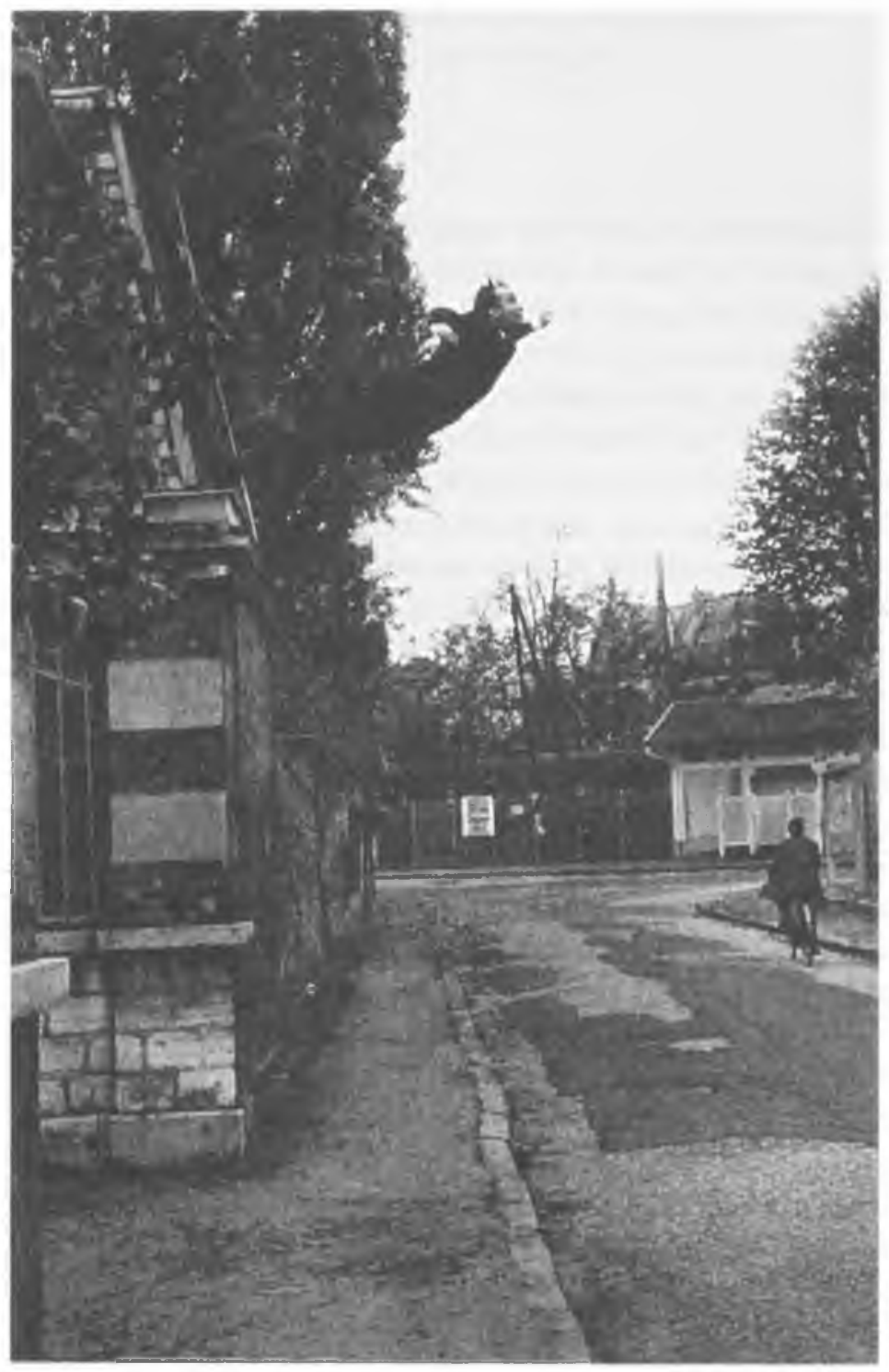




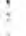

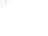<smiles>CCC[IH]</smiles> 


\section{MIJNHEER DE RECTOR MAGNIFICUS, DAMES EN HEREN,}

In de afgelopen weken heb ik nogal wat verbaasde reacties gehad op de aankondiging van deze oratie. Om twintig jaar na benoeming tot hoogleraar aan deze universiteit alsnog een inaugurele rede te houden zou getuigen van een wel erg secundair reactiepatroon. Bovendien zou ik daarmee bekennen mijn beroep twee decennia lang ongeoorloofd te hebben uitgeoefend!

De ware aanleiding tot deze oratie is een nieuwe functie en een daarmee samenhangende leeropdracht aan deze universiteit. Het lijkt mij redelijk op zo'n moment terug te blikken op de periode die ik achter mij laat en vooral zicht te geven op de plannen voor de toekomst. Volgens goed academisch gebruik vindt een dergelijke verantwoording in het openbaar plaats.

In deze oratie wil ik drie thema's bespreken: (1) de aard van de epidemie van hart- en vaatziekten in de afgelopen en in de komende jaren, (2) de rol van wetenschappelijk onderzoek in het bestrijden van deze epidemie, en tenslotte (3) zal ik een enkele beschouwing wijden aan de rol van onderzoeksscholen. De rode draad is de medische blik met als bindend element voor de drie thema's de vraag: Moed of Methode, oftewel hoe komt vooruitgang in wetenschappelijk onderzoek tot stand?

I $k$ wil dit verhaal over moed en methode laten beginnen in Wenen in het jaar 1846. In dat jaar bevonden zich in het park rond het Algemene Ziekenhuis twee identiek gebouwde kraamklinieken. Professor Klein leidde de ene kliniek, professor Bartsch de andere. Op 27 februari begaf de jonge chirurg Philipp Semmelweis zich door de ijzige kou naar zijn nieuwe werk als assistent van professor Klein. In de kraamklinieken speelde zich een groot 
drama af. De sterfte onder de kraamvrouwen was aanzienlijk. In de kliniek van professor Klein waren er periodes dat het risico te sterven bijna een op twee bedroeg. Deze tragedie viel niet alleen Semmelweis op. In de woorden van de schrijver Céline, die zijn proefschrift wijdde aan het leven en werk van Semmelweis: "Iedereen boog zijn hoofd als de plaag van de kraamvrouwenkoorts voorbij trok. Schijnheilig, in de schaduw van onverschilligheid, speelde iedereen onder én hoedje met de Dood". ${ }^{1}$

Zo niet Semmelweis. Semmelweis voelde zich buitengewoon betrokken bij het lot van de kraamvrouwen en wilde een einde maken aan hun wanhopige toestand. Enkele keizerlijke commissies hadden tevergeefs geprobeerd een remedie te vinden voor de kraamvrouwenkoorts. Ze zochten het in de vochtigheid, warmte, kou, maanstand, melk of in de neerslachtigheid van de vrouwen. Semmelweis ging anders te werk. Hij zag en begreep één eenvoudig gegeven: bij Klein stierven meer vrouwen dan bij Bartsch. Vervolgens zag Semmelweis in dat er bij Bartsch vroedvrouwen werden opgeleid en bij Klein medisch studenten. Tegen heftig verzet van Klein in, stelde Semmelweis voor de vroedvrouwen van Bartsch te vervangen door de studenten van Klein. De dood verhuisde met de studenten. Al snel zag en begreep Semmelweis dat Kleins studenten niet alleen assisteerden bij bevatlingen, maar ook, als onderdeel van hun opleiding, lijken ontleedden. Semmelweis' vondst de studenten hun handen te laten wassen, voordat zij met kraamvrouwen in aanraking kwamen, is briljant, als men zich realiseert dat het nog bijna een halve eeuw zou duren voordat Pasteur het bestaan van bacteriën ontdekte. Deze maatregel werd Semmelweis overigens fataal: Klein ontsloeg hem op 20 oktober 1846.

Semmelweis' verhaal is het verhaal van moed. In een sfeer waarin de dood van kraamvrouwen als onvermijdelijk werd aanvaard, had Semmelweis de kracht en de innerlijke overtuiging 
de sleutel te vinden tot de oorzalk van deze dood. Ik citeer Céline nogmaals: "De meest opmerkelijke eigenschap van degenen die zegevieren op het gebied van het wetenschappelijk onbekende is dat zij in staat zijn een bepaald probleem als essentieel te herkennen.... Gewone helderheid is niet voldoende, op dat moment heeft de onderzoeker een sterkere kracht nodig, een doordringende helderheid, even gevoelsmatig als bij jaloezie. Grote en exacte waarheden vloeien voort uit een geestdrift die meer met poëzie te maken heeft dan met strengheid van experimentele methodes". 1

De laatste jaren wordt het begrip serendipiditeit nog al eens gebruikt om onvoorspelbare wegen in het wetenschappelijk onderzoek te beschrijven. Het verhaal van Semmelweis en Céline toont dat serendipiditeit niet hetzelfde is als toeval. Grote ontdekkingen - of om een modewoord te gebruiken: top-wetenschap hangen niet van toeval af. Ze vergen een manier van kijken die wordt gevoed door geestdrift, innerlijke overtuiging en visie, kortom: moed.

Het verhaal van Semmelweis is niet alleen het verhaal van moed; het is ook een keerpunt in onze biologie. De levensverwachting in de vroege negentiende eeuw was niet veel anders dan die in antieke culturen of die in huidige derde-wereld landen, die nog steeds worden geteisterd door epidemieën van infectieziekten. Gemiddeld kon men rekenen op zo'n veertig jaar, waarbij te allen tijde een enkeling de honderd haalde. De weigering nog langer onder een hoedje met de Dood te spelen is een van de grootste prestaties van de negentiende eeuw. John Urquhart, Klaus Heilman en ik hebben een aantal jaren geleden uitgebreid geschreven over deze wending in de menselijke geschiedenis. ${ }^{2}$ Technologische en sociale innovaties zorgden er in vrij korte tijd voor dat de levensverwachting al in het begin van de twintigste eeuw met zo'n twintig jaar was toegenomen.

In het jaar 1900 waren infectieziekten en longaandoeningen, met name tuberculose, nog steeds belangrijker sterfte-oorzaken 
dan hart- en vaatziekten. Rond 1910 werden hart- en vaatziekten nummer één, en dat zijn ze de gehele eeuw gebleven. De piek werd in ons land, overig West-Europa en Noord-Amerika in 1972 bereikt, toen bijna de helft van de sterftes aan hart- en vaatziekten kon worden toegeschreven. ${ }^{3}$ Vooral hersenbloedingen en acute hartinfarcten maakten veel slachtoffers onder mensen van middelbare leeftijd.

De daling na 1972 wordt veroorzaakt door een complex van factoren, waarvan ik er vier noem:

1. Van enkele relatief zeldzame aandoeningen, zoals reumatische hartziekte, werd de oorzaak vastgesteld. Deze aandoeningen worden nu, mits tijdig opgespoord, met succes behandeld.

2. Een tweede factor is de buitengewoon effectieve manier waarop cardiologen de zorg voor de infarctpatiënt aanpakten. Hier geen berusting in de onvermijdelijkheid van de plotse Dood. In korte tijd werden er in ziekenhuizen eerste-harthulpvoorzieningen en 24-uurs hartbewakingsafdelingen ingericht. De behandeling van levensbedreigende ritmestoornissen werd effectief aangepakt. Procedures om verstopte kransslagaders op te sporen en te openen werden ontwikkeld en vanaf de jaren tachtig behoort snel herstel van de hartdoorbloeding met behulp van geneesmiddelen tot de standaardprocedures. Steeds meer patiënten werden behandeld op een moment dat er nog iets gedaan kan worden aan het voorkómen van een infarct. Door deze actieve aanpak is de vroege sterfte aan het acute myocardinfarct bij patiënten die het ziekenhuis halen binnen enkele decennia teruggelopen van ruim $30 \%$ tot minder dan $10 \% .^{4}$

3. Een derde factor was de geleidelijke herkenning van risicofactoren voor hart- en vaatziekten, zoals roken, hoge bloeddruk, hoog cholesterol en suikerziekte. Risicofactoren worden geïdentificeerd op basis van langdurige en grootschalige pros- 
pectieve bevolkingsonderzoeken. Het meest beroemde is het Framingham-onderzoek, genoemd naar het plaatsje Framingham in Massachusetts. Bij dit onderzoek werden in de jaren zestig duidelijke aanwijzingen gevonden voor de grote rol van risicofactoren. ${ }^{5}$ Vervolgens zijn vanaf diezelfde tijd effectieve campagnes gestart om risicofactoren terug te dringen op het niveau van de bevolking door organisaties als de Nederlandse Hartstichting .

4. De vierde factor is de steeds betere farmacotherapie van harten vaatziekten en hun risicofactoren. Hoge bloeddruk kan vanaf de jaren zeventig effectief worden behandeld. Vooral de indrukwekkende daling in de sterfte aan cerebrovasculaire incidenten is toe te schrijven aan antihypertensieve geneesmiddelen. Ik refereerde zojuist al aan de plaatjesaggregatieremmers en thrombolytica die de doorbloeding van het hart herstellen: Een te hoog cholesterolgehalte kan effectief en met duidelijke klinische resultaten worden verlaagd. Voor de behandeling van suikerziekte en haar schadelijke effecten op het hart-vaatstelsel bestaat een ruim arsenaal aan geneesmiddelen. Al deze geneesmiddelen zijn te koop voor een dagprijs die gelijk is aan één hamburger of één liter benzine. $U$ begrijpt dat ik trots en met plezier terugkijk op de farmacologie van de laatste vijfentwintig jaar. Toen Nietzsche in 1886 zijn Fröhliche Wissenschaft schreef, moet hij ongeveer de farmacologie van een eeuw later voor ogen hebben gehad. Immers, vrolijke wetenschap ontstat volgens Nietzsche pas op het moment dat iedereen toegang heeft tot datgene dat hem of haar bevrijdt van het sombere noodlot van de soort. ${ }^{6}$ Overigens is er een keerzijde aan dit succesverhaal van de farmacologie. Het woord farmacologie stamt uit het Grieks. In de Griekse cultuur was de pharmakos niet alleen de brenger van geneeskrachtige kruiden; hij was ook 
de zondebok ${ }^{7}$. Ik weet niet of Nietzsche onze beroepsgroep voor ogen had toen hij het begrip Antichrist introduceerde!

De bovengenoemde vier factoren tezamen hebben er toe geleid dat de sterfte aan cerebrovasculaire incidenten sinds 1972 met zo'n $70 \%$ is verminderd en die aan het acute myocardinfarct met ruim 50\%. De International Herald Tribune sprak op 7 augustus jl. over deze cijfers als zijnde "one of the greatest accomplishments of the century". 8

Voor deze prestatie is niet één twintigste-ecuwse Semmelweis verantwoordelijk, hoewel er talrijke moedige onderzoekers zouden kunnen worden genoemd, die voor deelsuccessen verantwoordelijk zijn. Ook politiek lobbyisme van het type War on cancer of Decade of the brain met zijn impliciete beloftes van snel succes ligt niet ten grondslag aan deze resultaten. Hier is veel meer sprake van het succes van de methode, stapje voor stapje, waarbij methode cartesiaans moet worden begrepen als de wisselwerking tussen het mechanistisch en numeriek denken.

In een bijzonder verhelderend artikel in de Lancet van een jaar geleden ${ }^{9}$ zet de Leidse epidemioloog Vandenbroucke de methodologische basis van het twintigste-eeuws medisch wetenschappelijk onderzoek uiteen. Hij onderscheidt hierbij de mechanistische en de numerieke manier van denken. Het mechanistisch denken zoekt op deterministische basis verklaringen voor ziekteverschijnselen in de individuele patiënt of in het proefdier. Deze vorm van denken vindt zijn oorsprong in het pathofysiologisch redeneren; de causaliteit staat centraal en de observatie en het experiment zijn de belangrijkste methoden. Onder het numerieke denken wordt verstaan de statistische en epidemiologische aanpak, waarvan het Framingham-onderzoek zo'n fraai voorbeeld is. Ook de talrijke trials gericht op het vaststellen van de klinische effectiviteit van geneesmiddelen zijn voorbeelden van het numerieke denken. ${ }^{10}$ Het samenspel van de mechanistische en numerieke aanpak heeft 
de medische wetenschappen in de twintigste eeuw een geheel eigen methodologische basis gegeven die hen epistemologisch definitief onderscheidt van andere wetenschappen.

Dit zou een mooi moment kunnen zijn te stoppen en tevreden een gezond glas wijn te gaan drinken. Karl Kraus wist in het begin van deze eeuw al dat mensen niet naar een lezing komen - en zeker niet naar een medische - om goed nieuws te horen. Bovendien zou ik $\mathbf{u}$ dan met een onjuist en te optimistisch beeld achterlaten. Waarom zijn hart- en vaatziekten nog steeds de grootste oorzaak van sterfte? Waarom zullen deze ziekten dat in de eenentwintigste eeuw zelfs op wereldwijde schaal worden? ${ }^{11}$ Waarom nemen de ziektelast en de daarmee samenhangende kosten ten gevolge van hart- en vaatziekten toe, in plaats van af? Wellicht zal de sterfte zelfs weer toenemen als de baby-boomgeneratie de zestig jaar gaat passeren. De grootste sterfte zal dan misschien niet meer optreden op middelbare leeftijd, maar later. In onze cultuur in de eenentwintigste eeuw echter zullen ziekte en sterfte op een leeftijd van vijfenzestig of zeventig en zelfs vijfenzeventig jaar niet langer als onvermijdelijk worden beschouwd. Bovendien is het beslist onjuist de toenemende sterfte aan hart- en vaatziekten uitsluitend aan veroudering van de bevolking toe te schrijven. Ik noem drie aanvullende oorzaken voor het standhouden en zelfs toenemen van hart- en vaatziekten.

Ten eerste is het terugdringen van risicofactoren maar beperkt succesvol. Al jaren neemt de verkoop aan sigaretten in ons land niet af. ${ }^{12}$ Rookgedrag en voedingsgewoonten blijken op korte termijn moeilijk beïnvloedbaar. Gezondheidsvoorlichting en -interventie zijn inmiddels vakgebieden waarop talrijke studies worden verricht ter verbetering van gezond gedrag. Wij hebben in dit verband al eens gewezen op de wenselijkheid van een eenvoudige kwantitatieve risicomaat in het algemene taalgebruik. ${ }^{2}$ ledereen begrijpt de waarde van de florijn of de kilogram en zelfs 
van de Richter-eenheid voor aardbevingen, maar een (meet)eenheid die aangeeft hoe risicovol een bepaald gedrag is ontbreekt nog: op dat gebied zijn wij, midden in dit computertijdperk, als Neanderthalers.

Ook op voedingsgebied groeit geleidelijk het inzicht hoe risico's voor hart- en vaatziekten beter kunnen worden beïnvloed. Bovendien worden er nog steeds nieuwe risicofactoren voor harten vaatziekten ontdekt. Vooral in de sfeer van hormonen en bloedstolling blijken er belangrijke risicofactoren te bestaan, zoals oestrogeentekort, fibrinogeen, weefselplasminogeenactivator en proteïne C. In hoofdlijn I van het CARIM-programma worden de nieuwe risicofactoren op het gebied van de bloedstolling grondig bestudeerd.

Ten tweede bereiken de talrijke geneesmiddelen voor de behandeling van hart- en vaatziekten slechts een beperkt effect. Eén oorzaak hiervan is het niet-optimale voorschrijfgedrag van artsen. Ruim $40 \%$ van de patiënten met hart- en vaatziekten krijgt niet de optimale therapie voorgeschreven. ${ }^{3}$ Van hen die dit wel krijgen, slikt zeker $20 \%$ de voorgeschreven middelen niet of onregelmatig. ${ }^{13}$ Ter illustratie van dit laatste: het gedurende één weekeinde overslaan van een eenvoudige dagelijkse plaspil ter behandeling van hartfalen kan leiden tot een acute ziekenhuisopname op zondagnacht wegens asthma cardiale. De kosten van zo'n ziekenhuisopname zijn meer dan 10.000 keer groter dan de prijs van de twee vergeten pillen.

Het is onbegrijpelijk - om geen sterker woord te gebruiken dat het huidige politieke debat over de kwaliteit van de gezondheidszorg zo sterk wordt gedomineerd door kostenaspecten van de geneesmiddelentherapie, als we ons realiseren dat meer dan 50\% van de mensen die lijden aan de grootste volksziekte geen optimale therapie ontvangt. Alleen al in Nederland betekent dit een verhoogd sterfte- en ziekterisico voor duizenden mensen per jaar. 
Een einde aan deze schande kan worden gemaakt door onder andere nog intensievere aandacht voor de farmacotherapie in de opleiding en nascholing van artsen, beter gecontroleerde farmacotherapie van de hart-en-vaatziektenpatiënt en maatregelen ter verhoging van de therapietrouw met behulp van moderne electronica en informatietechnologie.

De derde - en meest fundamentele - oorzaak van het standhouden van de hart- en vaatziekten is te wijten aan wat ik zou willen noemen "de erosie van het pathofysiologisch denken" in de medische wetenschappen. Ik heb u zojuist geschetst hoe effectief we hoge bloeddruk, beroertes en acute myocardinfarcten kunnen behandelen. Dit kunnen we zien als de triomf van de numerieke methode, die de grondslag vormde voor de behandeling van deze aandoeningen. De triomf is echter slechts een gedeeltelijke overwinning. De numerieke methode gaat uit van een standaardbehandeling van patiëntgroepen, waardoor onvoldoende rekening wordt gehouden met verschillen in individuele gevoeligheden. Bovendien is deze aanpak gericht op aandoeningen die het eindresultaat zijn van langdurige onderliggende ziekteprocessen. Het doel van de therapie ligt weliswaar dicht bij de doodsoorzaak, maar niet noodzakelijkerwijs bij het ziekteproces, dat soms al tientallen jaren eerder is begonnen. Over de aard van de ziekteprocessen en hun specifieke bijdragen aan de cardiovasculaire sterfte weten we nog opvallend weinig.

Een ernstig gevolg hiervan is dat de behandeling van acute vormen van hart- en vaatziekten een nieuwe epidemie van andere cardiovasculaire aandoeningen an het blootleggen is. Ik doel hierbij op hartfalen, boezemfibrilleren en vaatlijden. $\mathrm{Nu}$ al is hartfalen de grootste oorzaak van ziekenhuisopnames in mensen boven vijfenzestig jaar. ${ }^{14}$ Ook het aantal ziekenhuisopnames voor boezemfibrilleren is de laatste twee decennia sterk toegenomen. ${ }^{3}$ Hartfalen en hartritmestoornissen zijn de centrale onderwerpen 
van onderzoek de komende jaren binnen de tweede hoofdlijn van het CARIM-onderzoek.

Op het gebied van vaatlijden schat een recente Nederlandse studie de prevalentie aan perifeer vaatlijden op $20 \%$ van de bevolking boven vijfenvijftig jaar. ${ }^{15}$ Over vaatlijden zijn nog weinig precieze cijfers bekend, simpelweg als gevolg van het feit dat onze gezondheidszorg niet is ingericht op het systematisch opsporen, diagnosticeren en behandelen van vaataandoeningen. Als je kiespijn hebt, ga je naar een tandarts. Een vaatprobleem kan echter boven tafel komen bij de chirurg, de nefroloog, de neuroloog, de cardioloog, de endocrinoloog, de dermatoloog, de radioloog of zelfs de uroloog, aangezien potentiestoomissen soms berusten op vaatvernauwing. Het is verheugend dat in diverse ziekenhuizen, waaronder het Academisch Ziekenhuis Maastricht, een start is gemaakt met doelgerichte aandacht voor de patiënt met vaatlijden. Ik voorspel dat zo'n verandering van aandacht op den duur grote positieve gevolgen zal hebben voor de cardiovasculaire ziektelast en sterfte. Hoofdlijn III van het CARIM-programma is gericht op vaatonderzoek. Een team van klinisch en basaal-wetenschappelijke onderzoekers zal zich in de komende jaren geconcentreerd richten op de oorzaken, de vroege opsporing en de behandeling van vaataandoeningen.

Ik wil het laatste deel van deze oratie besteden aan de vraag hoe een versterking van het pathofysiologisch denken een verdere eliminatie van hart- en vaatziekten kan bewerkstelligen. Daarbij zal ik trachten de positie van CARIM in de komende jaren aan te geven.

Het pathofysiologisch denken vindt zijn oorsprong in de negentiende-eeuwse Parijse school, waarvan Claude Bernard de belangrijkste vertegenwoordiger is. Voor Bernard stonden observatie en experiment centraal in het toetsen van een hypothese. Een experiment kan worden verricht aan een patiënt, maar ook aan een 
proefdier, of een geïsoleerd orgaan of weefsel. De observatie aan de rand van het bed van de patiënt speelt een centrale rol in het klinisch pathofysiologisch denken. In de loop van de twintigste eeuw is die vorm van observeren steeds meer vervangen door het laboratorium, aanvankelijk het microbiologisch laboratorium, later het klinisch chemisch laboratorium en tegenwoordig het moleculair biologisch/genetisch laboratorium. De recente explosie van moleculair biologische laboratoriumtechnologie betekent mijns inziens geen breuk in de conceptuele basis van het pathofysiologisch denken. Integendeel, de moleculaire biologie - mits juist geplaatst - biedt een nieuwe laag voor mechanistische verklaringen van ziekten.

Het lijkt er op alsof kliniek en pre-kliniek/laboratorium op dit ogenblik verder dan ooit van elkaar verwijderd zijn. Op sommige medische campussen in de Verenigde Staten is dit ook werkelijk zo. Dit beeld wordt veroorzaakt door het tempo van de ontwikkelingen in de laboratoriumwetenschappen. Het doet denken aan de explosieve ontwikkeling van de experimentele natuurkunde in de eerste helft van deze eeuw. In beide gevallen was een golf van nieuwe technologie de oorzaak van een sterke groei van nieuwe, experimentele wetenschapsgebieden. De Nederlandse fysicus en oud-KNAW-president Casimir heeft er in zijn boek Het toeval van de werkelijkheid ${ }^{16}$ op gewezen dat de wisselwerking tussen wetenschap en technologie tot een spiraalsgewijze vooruitgang van kennis leidt. Van de vele verklaringen voor de vooruitgang in kennis komt dit model van Casimir mij voor als de meest geschikte en universele beschrijving.

De golf van nieuwe biomedische technologie betreft een aantal terreinen. Ik noem bijvoorbeeld de informatie- en beeldbewerkingstechnologie, de microscopie en spectroscopie, nieuwe biomaterialen en kunstmatig ontwikkelde weefsels en organen. Op moleculair gebied zijn de ontwikkelingen zelfs ronduit spectacu- 
lair. Tien jaar geleden bestudeerde een biomedisch onderzoeker één gen of één eiwit tegelijkertijd. Gensequenties worden nu opgehelderd met een snelheid van honderden megabases per maand. Op chips ter grootte van uw vingertop wordt de expressie van tienduizenden genen in één keer gemeten. Robots in farmaceutische bedrijven synthetiseren honderdduizenden eiwitten of andere kandidaat-geneesmiddelen in één maand.

Het medisch onderzoek zal een antwoord moeten vinden op dit overweldigende aanbod van nieuwe technologie. Eén antwoord hebben wij locaal gegeven in de vorm van het recente initiatief van de opleiding BiomedischTechnologie als samenwerking tussen de Technische Universiteit Eindhoven en de Universiteit Maastricht. Deze opleiding schoolt studenten in de basisvakken die ten grondslag liggen aan de biomedische technologie en laat ze intensief kennis maken met de werelden van de kliniek, het laboratorium en de industrie.

Een ander antwoord op de technologieuitdaging is dat we steeds goed het doel van het medisch onderzoek voor ogen moeten houden: het opsporen en behandelen van ziekte. Wat betekent dit voor het hart- en vaatziektenonderzoek? Deze vraag beantwoord ik graag met de gentechnologie als voorbeeld.

De grootste uitdaging voor het hart- en vaatziektenonderzoek van dit ogenblik is de vertaling van de omvangrijke moleculaire informatie in pathofysiologische concepten omtrent ziekte. Binnen enkele jaren zal de structuur van het gehele menselijke genoom zijn opgehelderd. Van de circa 100.000 genen worden er tussen de 15.000 en 30.000 tot expressie gebracht in iedere cel die zich in het hart- en vaatstelsel bevindt ${ }^{17}$. Een groot deel van deze genen is verantwoordelijk voor allerlei basale celfuncties. Er zijn echter ook subsets van genen betrokken bij de specifieke functies van hart en bloedvaten. De normale functie van het hart-vaatstelsel ontstaat in de loop van de ontwikkeling van iedere mens en is het 
gevolg van een verfijnd samenspel van erfelijke aanleg en invloeden uit de omgeving, zoals het zuurstofaanbod of de mechanische krachten die worden uitgeoefend op de wand van hart en vaten. Hierbij heeft het hart-vaatstelsel een opvallend vermogen tot voortdurende aanpassing aan veranderde omgevingsfactoren. Als het aanpassingsvermogen verloren gaat, bijvoorbeeld door langdurige blootstelling aan een risicofactor, wordt een ziekteproces in werking gezet. In ons eigen onderzoek van de latste jaren hebben wij onder andere bestudeerd hoe afwijkingen in de groei van bloedvaten aanleiding kunnen geven tot aandoeningen als hoge bloeddruk en hartfalen ${ }^{18}$. Het therapeutisch herstel van de bloedvatgroei is inmiddels een fundamenteel nieuwe mogelijkheid voor de behandeling van sommige hart- en vaatziekten, gebaseerd op pathofysiologische inzichten ${ }^{18}$.

Over de rol van genetische factoren in de ontwikkeling van het hart-vaatstelsel groeit onze kennis snel. De meeste genen zijn slechts heel kortstondig actief tijdens de ontwikkelingsfase. Daarna blijven ze stil, totdat een externe prikkel ze weer activeert. De CARIM-onderzoeker Matthijs Blankesteijn uit de groep van Jos Smits heeft - als voorbeeld - recent beschreven hoe na een hartinfarct het frizzled gen wordt geactiveerd ${ }^{19}$. Dit gen is al jaren geleden beschreven in fruitvliegjes en zorgt in die diertjes voor het keurig op een rij groeien van de haartjes op de vleugels. Ditzelfde gen - dat we een polariteitsgen noemen - lijkt er in het hart voor te zorgen dat er een keurig, in de ruimtelijke structuur van het hart gecoördineerd proces van wondgenezing optreedt na een infarct. Hiermee wordt dit typisch embryonaal actieve polariteitsgen ineens op volwassen leeftijd onderdeel van een fysiologisch regelen herstelmechanisme.

Dit brengt mij op de positie van CARIM in de komende jaren. Met zijn - door Rob Reneman zo krachtig geïntroduceerde traditie op het gebied van de pathofysiologie is CARIM uitste- 
kend toegerust om het moderne hart- en vaatziektenonderzoek tegemoet te treden. Sterker nog, CARIM wil daarin internationaal toonaangevend zijn. Het recente besluit van de besturen van de universiteit, de faculteiten Geneeskunde en Gezondheidswetenschappen en het academisch ziekenhuis substantieel te investeren op de gebieden ontwikkelingsbiologie, moleculaire biologie en populatiegenetica getuigt van goede visie. Voor CARIM zullen hartfalen, ritmestoornissen en vaatlijden - drie gezichten van de huidige cardiovasculaire epidemie - centrale onderwerpen zijn voor de komende jaren. Deze klinische blik wordt gevoed door een krachtige laboratoriuminfrastructuur. De samenwerking met de Technische Universiteit Eindhoven in het kader van de opleiding Biomedische Technologie geeft hierbij een sterke impuls aan de zo wenselijke wetenschap-technologiespiraal. De talrijke vormen van nationale en internationale samenwerking zijn een conditio sine qua non voor het moderne medische onderzoek.

Universitaire onderzoeksinstituten en scholen zijn in Nederland een nieuw fenomeen, althans in de geformaliseerde vorm waarin ze thans bestaan. In de eerste tien jaar van hun bestaan heeft de aandacht - wellicht onvermijdelijk - sterk gelegen op de structuur en organisatie. De komende jaren kan de aandacht wat meer gericht worden op de cultuur die hoort bij "top"-wetenschap. Kenmerken van die cultuur zijn een hoog ambitieniveau, professionaliteit en grote, geconcentreerde inspanning, maar ook integriteit, aandacht voor het ontwikkelen van talent, respect voor individuele kwaliteiten en gastvrijheid.

In ons land is er in de afgelopen jaren een bijna pathologische behoefte gegroeid aan beoordeling van onderzoek en onderzoeksscholen. CARIM is in tien jaar tijd tenminste zes keer onderwerp geweest van locale, nationale of internationale beoordeling. Ik vrees dat we hier te maken hebben met een uiting van de postmodeme cultuur, waarin organisaties - en individuen - voortdurend 
en steeds opnieuw hun context moeten bepalen. Het mobiele-telefoongebabbel in de trein, op vliegvelden of aan het strand is de karikatuur van deze cultuur. De Amerikaanse socioloog Richard Sennet heeft recent de persoonlijke gevolgen van zo'n cultuur van netwerken en voortdurende controle geschetst in zijn boek, getiteld The corrosion of character. ${ }^{20}$ Dames en heren, medewerkers van CARIM, als uw nieuwe wetenschappelijk directeur acht ik het mijn taak uw karaktercorrosie te voorkomen. Ik zal dat niet doen door mobiele telefoons te verbieden. Veeleer zal ik proberen uw geestdrift en overtuiging aan te wakkeren. Van $u$ verwacht $i k$ professionaliteit en een eerlijk inzicht in uw eigen talenten. Ik heb $u$ geschetst hoe belangrijk de methode is om vooruit te komen; sommigen van u wens ik de moed en het zo bijzondere vermogen tot kijken én begrijpen. 


\section{DAMES EN HEREN,}

Deze oratie ging, behalve over moed en methode, over kijken en visie. Mijn eigen blik - visie is hier een te groot woord - is gevormd door de steun en het vertrouwen van velen. Ik beschouw het als een voorrecht aan het einde van deze rede enkelen hiervoor te danken.

Ik dank de leden van het bestuur van de universiteit, faculteit, academisch ziekenhuis en CARIM voor de steun die ik vanaf mijn benoeming in Maastricht ondervind. Van de vele bestuurders noem ik er een in het bijzonder. Dat is Edward Steur, niet alleen als bestuurder, maar ook als vriend een constante factor in mijn leven van de laatste decennia.

De leden van de capaciteitsgroep Farmacologie en Toxicologie dank ik voor hun niet aflatende inzet. Afscheid te nemen als uw voorzitter is voor mij een minder vrolijk aspect van deze dag. Jos Smits is echter een voortreffelijk opvolger, die u kundig verder zal leiden. Els Geurts en Mia Hogenboom zijn niet alleen uitstekende secretaresses; menigmaal openden zij mijn ogen waar ik blind was. Helma van Essen, analiste van het eerste uur: in jou bedank ik de hele technische staf van de groep voor jullie constant hoge niveau van prestaties.

Promovendi zijn misschien wel het dierbaarste dat aan een hoogleraar wordt toevertrouwd. Jullie hebben er in elk geval voor gezorgd dat het biologische vaderschap enkele verrassingen minder voor mij met zich meebracht.

Mijn wetenschappelijke blik is en wordt gevormd door mijn opleiders en collegae. Ik noem allereerst Jacques van Rossum, mijn promotor. Jouw vrije geest is een verademing in een universitaire 
cultuur waarin normen helaas vaak de vorm aannemen van bureaucratische regels.

Pieter van Zwieten: als prominent farmacoloog heb $\mathrm{jij} \mathrm{mij}$ geïntroduceerd en met vriendschap begeleid in talrijke internationale kringen van ons vak.

Rob Reneman: ik heb grote bewondering voor de wijze waarop je CARIM hebt gecreëerd en geleid. Ik vind het een eer jou te mogen opvolgen.

John Urquhart: your vision on almost any aspect of medical sciences and life at large has been a rich source of inspiration for me during the past twenty-five years.

Bernard Lévy: Dans le domaine de la pensée physiopathologique, la fameuse école Parisienne a trouvé en votre personne un représentant contemporain de qualité exceptionelle.

Tenslotte, de ware blik ontstaat pas in intimiteit.

Sam en Ramses, jullie zijn onze hartelapjes. Ik kijk en geniet met jullie in de buurt.

Ardi, jouw blik is mijn baken. 


\section{NOTEN}

1 CÉline LF. La vie et l'oeuvre de Philippe Ignace Semmelweis. Als proefschrift in 1924 verschenen. Opnieuw uitgegeven door Gallimard in 1977. Nederlandse vertaling: Semmelweis. De Arbeiderspers, 1986

2 STRUIJKER BOUDIER HAJ, K HEILMAN En J URQUHART. Risico's meten: een antwoord op de angst voor een technologische cultuur. In den Toren, Baarn, 1985

3 BRAUNWALD E. Shattuck Lecture: Cardiovascular medicine at the turn of the millennium: triumphs, concerns, and opportunities. New Engl J Med 337: 1360-1369, 1997

4 Dit getal is gebaseerd op een aantal internationale en landelijke analyses. Vergelijkbare cijfers voor de regio Maastricht worden besproken in het proefschrift Acute Coronary Syndromes in the Maastricht Area van $\mathrm{J}$ Widdershoven en $\mathrm{K}$ de Vreede-Swagemakers, Universitaire Pers Maastricht, 1997

5 KANNEL WB, TR DAWBER, A KAGAN, N REVOTSKIE and J STOKES. Factors of risk in the development of coronary heart disease - a six year follow-up experience: the Framingham Study. Ann Intern Med 55: 33-50, 1961

6 NIETZSCHE F. Fröhliche Wissenschaft. Nederlandse vertaling: Vrolijke wetenschap. De Arbeiderspers, 1976

7 Op deze dubbele betekenis van het woord pharmakos ben ik attent gemaakt door collega A. Labrie in zijn oratie Het verlangen naar zuiverheid. Een essay over Duitsland, Universiteit Maastricht, 1994

8 KOLATA G. Cardiovascular death rates plummet in U.S. Int Herald Tribune, August 7, 1999

9 VANDENBROUCKE JP. Clinical investigation in the 20th century: the ascendancy of numerical reasoning. Lancet 352: SII 12-SII 16, 1998 
10 In de laatste twee decennia zijn er alleen al op hart- en vaatziektengebieden honderden van dergelijke trials uitgevoerd. Een voorbeeld van de enorme schaal - en navenante kosten! - van dergelijk onderzoek: ACE-Inhibitor Myocardial Infarction Collaborative Group: Indications for ACE Inhibitors in the early treatment of acute myocardial infarction. Circulation 97: 2202-2212, 1998

11 MURRAY CJ and AD LOPEZ. Global burden of disease. Science 274: 740-743, 1996

$12 \mathrm{Al}$ jaren worden er in Nederland jaarlijks circa 16 miljard sigaretten verkocht. Gegevens ontleend aan NRC/Handelsblad 31 juli 1999

13 Deze getallen zijn gebaseerd op een aantal analyses. De situatie in de USA wordt goed samengevat in The sixth report of the joint national committee on prevention, detection, evaluation, and treatment of high blood pressure. Arch Int Med 157: 2413-2446, 1997; voor Europa - inclusief Nederland - is de Euroaspire studie een goede bron: European Heart J 18: 1569-1582, 1997

14 GHEORGHIADE $M$ and RO BONOW. Chronic heart failure in the United States. A manifestation of coronary artery disease. Circulation 97: 282-289, 1998

15 MEIJER WT, AW HOES, D RUTGERS, ML BOTS, A HOFMAN, DE GROBBEE. Peripheral arterial disease in the elderly. The Rotterdam Study. Arterioscler Thromb Vasc Biol 18: 185-192, 1998

16 CASIMIR HBG. Het toeval van de werkelijkheid. Meulenhoff, Amsterdam, 1983

17 HWANG DM, AA DEMPSEY, R-X WANG, M REZVANI, D BARIRANS, K-S DAI, H-Y WANG, H MA, E CUKERMAN, Y-Q LIU, J-R GU, J-H ZHANG, SKW TSUI, MMY WAYE, K-P FUNG, C-Y LEE, and C-C LIEW. A genome-based resource for molecular cardiovascular medicine. Toward a compendium of cardiovascular genes. Circulation 96: 4146-4203, 1997 
18 LE NOBLE FAC, FRM STASSEN, WJG HACKING, and HAJ STRUIJKER BOUDIER. Angiogenesis and hypertension. J Hypertens 16: 1563-1572, 1998

19 BLANKESTEIJN WM, YPG ESSERS-JANSSEN, MJA VERLUYTEN, MJAP DAEMEN, and JFM SMITS. A homologue of Drosophila tissue polarity gene frizzled is expressed in migrating myofibroblasts in the in farcted rat heart. Nature Med 3: 541-544, 1997

20 SENNETT $R$. The corrosion of character. Norton and Company, New York, 1998 
Gino de Dominicus, "Tentativo di volo / Vliegpogingen" 1970. 

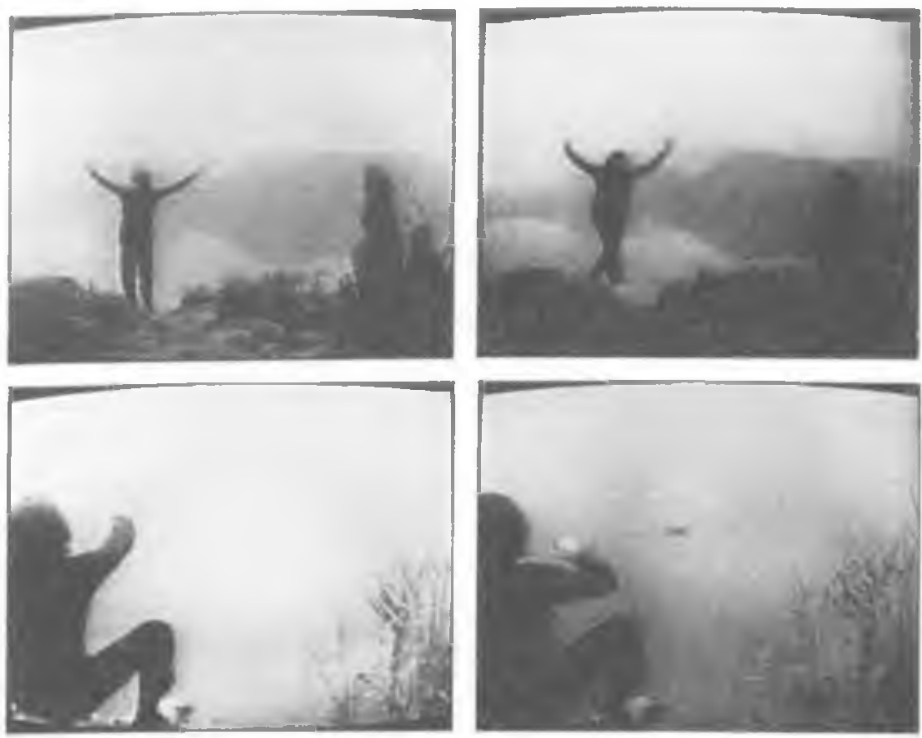

\section{a}

Identifications, 1970

z/w, g, 1'55"

Aan het begin van het werk verstrekt De Dominicis de volgende informatie die het concept van het werk vormt: 'Misschien omdat ik zwemmen kan, besloot ik te leren vliegen. Sinds drie jaar herhaal ik deze oefening. Het is mogelijk dat ik mijn doel nooit bereik. Maar wanneer ik mijn zoon ertoe kan overhalen, door te gaan met deze oefening. en zo ook de zonen van mijn zoon, dan zal misschien éen van mijn nakomelingen op een dag ontdekken, dat hij weet hoe hij moet vliegen'. Vervolgens laat hij zijn oefeningen zien. Hij gaat op een heuveltje staan, strekt zijn armen uit, maakt vliegbewegingen door steeds sneller met zijn armen rond te draaien, iets door zijn knieen te zakken, en tenslotte van het heuveltje af te springen. Hij herhaalt dit vijfmaal. Oefening baart kunst. 